\title{
Oligoartiküler Juvenil İdiopatik Artrit Hastalarının Aktif ve İnaktif Dönemdeki Sitokin Düzeylerinin Değerlendirilmesi
}

\author{
Evaluation of Cytokine Levels of Oligoartiular Juvenile Idiopathic \\ Artrithis Patients in Active and Inactive Period

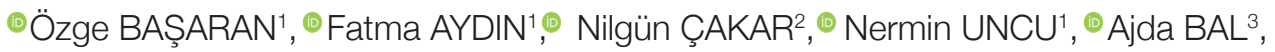

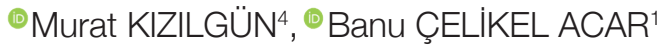

'`S.B.Ü, Ankara Çocuk Sağlığı Hastalıkları, Hematoloji Onkoloji SUAM, Çocuk Romatoloji Kliniği, Ankara, Türkiye

${ }^{2}$ Ankara Üniversitesi Tıp Fakültesi, Çocuk Sağlığı ve Hastalıkları Anabilim Dalı, Çocuk Nefroloji ve Romatoloji Bilim Dalı, Ankara, Türkiye

${ }^{3}$ S.B.Ü, Ankara Dışkapı Yıldıım Beyazıt SUAM, Fiziksel Tıp ve Rehabilitasyon Kliniği, Ankara, Türkiye

${ }^{4}$ S.B.Ü, Ankara Çocuk Sağlı̆̆ı Hastalıkları, Hematoloji Onkoloji SUAM, Biyokimya Bölümü, Ankara, Türkiye

Bu yazı 4. Çocuk romatoloji kongresi (4-7 Nisan 2018, Bodrum, Türkiye)'nde poster bidirimi olarak sunulmuștur.

\section{öz}

Amaç: Juvenil idiopatik artrit (JIA) çocukluk çağının en sık görülen romatolojik hastalığıdır. Kısa ve uzun dönemde ciddi morbiditelere yol açabilir. JiA'da hastalık aktivasyonu klinik değerlendirme ve inflamasyonun bilinen belirteçleri ile gösterilebilir. Ancak günümüz pratiğinde bu iki parametre her zaman birbiri ile uyum içerisinde olmamakta, bu durumda da özellikle tedavinin planlanmasında ve izleminde zorluklara yol açmaktadır. Bu çalışma ile amacımız interlökin-1 $\beta$ (IL-1ß), interlökin-6 (IL-6), tümör nekrozitan faktör alfa (TNF-a)'nın oligoartiküler Ji'A'da hastalık aktivitesini göstermede kullanılabilirliğini araştırmaktır.

Gereç ve Yöntemler: Yeni tanı almış 13 oligoartiküler JïA hastası ve 8 sağlıklı kontrol çalışmaya dâhil edildi. Hastaların başvurularında ve inaktif dönemlerinde IL-1 $\beta$, TNF-a ve İ-6 düzeyleri bakıldı. Hastaların aktivite ve yaşam kalitesi ölçümleri için JADAS-27 (Juvenile Arthritis Disease Activity Score) ve JAQQ (Juvenile Arthritis Quality of Life Questionnaire) kullanıldı.

Bulgular: Hastaların aktif dönemlerinde bakılan IL-6, IL-1 $\beta$ ve TNF-a düzeyleri ile inaktif dönem ve kontrol grubu arasında anlamlı farklılık saptanmadı. Hastaların ilk bașvurularındaki JADAS-27 skorları ile inaktif dönemdeki JADAS-27 skorları karşılaştıııdığında inaktif dönemde skorda anlamlı azalma olduğu saptandı ( $p=0.02)$. Hastaların JAQQ puanları karşılaştırılığında ise gruplar arasında anlamlı farklılık saptanmadı ( $p=0.382)$. JADAS-27 puanları >10 ve $\leq 10$ olanların sitokin düzeyleri karşılaştıııdığında, düşük puana sahip hastalarda İL-1ß düzeyi anlamlı olarak düşük saptandı. İL-6 ve TNF-a düzeyleri için ise fark anlamlı bulunmadı.

Sonuç: Juvenil idiopatik artrit hastalarında aktivasyonun ve remisyonun değerlendirilmesi için çeşitli laboratuvar değerleri ve aktivite skorları kullanılmaktadır. Sonuçlarımız ve literatür ışığında bakıldığında oligoartiküler JiA hastalarında sitokin düzeylerinin hastalık izlem ve aktivitesininin değerlendirilmesinde kullanılabilirliği kısıtıdır.

Anahtar Sözcükler: Sitokin, Juvenil idiopatik artrit, İnterlökin-1ß, İnterlökin-6, Tümör nekrozitan faktör

\begin{abstract}
Objective: Juvenile idiopathic arthritis (JIA) is the most common rheumatologic disorder in childhood. It may cause short and long-term morbidities. Disease activity assessment in JIA patients is based on clinical examination and conventional parameters of inflammation. However, those parameters are not always in concordance and there could be difficulties in planning of therapy and management. The aim of this study is to evaluate the role of interleukin-1 $\beta$ (IL1ß), interleukin-6 (IL-6), tumor necrosis factor alfa (TNF-a) in determining disease activity of JIA patients.

Material and Methods: Thirteen new diagnosed oligoarticular JIA patients and eight healthy controls were enrolled in the study. We investigated serum levels of IL-1 $\beta$, TNF- $a$ and IL- 6 during both active and inactive phases of the disease. To evaluate the disease activity and quality of life we used JADAS-27 (Juvenile Arthritis Disease Activity Score) and JAQQ (Juvenile Arthritis Quality of Life Questionnaire).
\end{abstract}


Results: There were no statistically significant differences regarding IL-6, IL-1 $\beta$ and TNF-a between the active phase, inactive phase and control group. Comparing JADAS-27 scores, there was a statistically significant decrease in inactive period compared with the active period ( $\mathrm{p}=0.02$ ). However, no significant difference was obtained about the JAQQ scores between active and inactive stages ( $\mathrm{p}=0.382$ ). Levels of IL-1 $\beta$ were significantly decreased in patients with low disease activity (JADAS-27 score $\leq 10$ ) compared with those of severe and moderate disease activity (JADAS-27 score >10). On the other hand, no significant difference was obtained for IL-6 and TNF-a.

Conclusion: There are few methods to evaluate the activation and remission periods of JiA. According to our results and the literature assessment of cytokine levels has limited value in diagnosis, monitoring and evaluating the severity of the oligoarticular JIA patients.

Key Words: Cytokine, Juvenile idiopathic arthritis, Interleukin-1 $\beta$, Interleukin-6, Tumor necrosis factor

\section{GiRiș}

Juvenil idiopatik artrit (JiA), 16 yaşından önce başlayıp en az 6 hafta süren, en az bir eklemin tutulduğu ve altta yatan nedenin belirlenemediği artrit olarak tanımlanır. JiA çocukluk çağında kısa ve uzun dönemde ciddi morbiditelere yol açar. Aynı zamanda çocukluk çağının en sık görülen romatolojik hastalığıdır. Etiyopatogenezi bilinmemekle birlikte, değişken immünite, anormal immünoregülasyon mekanizmaları ve sitokin üretimi gibi pek çok sebep üzerinde durulmaktadır $(1,2)$.

JiA hastalarında hastalık aktivitesinin değerlendirilmesi klinik incelemenin temel parçalarından birisini oluşturmaktadır. Genel olarak aktivite değerlendirmesi fizik muayene ve inflamasyon parametreleri ile yapılmaktadır. Ancak günümüzde tedavi seçeneklerini belirlemede bu iki parametre yeterli olmamaktadır, bunun yanı sıra JiંA tanısı için altın standart denebilecek bir yöntem yoktur. Bu nedenle, hastalık aktivitesini gösterebilecek duyarlı, güvenilir ve geçerli belirteçlere intiyaç vardır (3). Sitokinler otoinflamatuvarve otoimmünhastalıklardaimmünve inflamatuvar reaksiyonlarda görev yapan hücrelerin maturasyonunda, başkalaşmasında ve aktivasyonunda görevli küçük protein parçacıklarıdır. İnflamatuvar sitokinlerden interlökin-1 (IL-1), interlökin-6 (IL-6) ve tümör nekrozitan faktör alfa (TNF-a) pek çok inflamatuvar ve enfeksiyöz hastalık ile ilişkilendirilmiştir. Yine pek çok çalışmada Ji'A' da inflamatuvar sitokinlerin rolü tartışımıştır $(4,5)$. İ-1 sistemik ve eklem inflamasyonunda rol alan bir sitokindir. İL-1 $\beta$ ve TNF-a eklemdeki destrüktif süreç sonucunda prostaglandinlerin ve proteazların salınımını başlatır ve aynı zamanda kıkırdak rezorbsiyonunu indükler. İmmün ve inflamatuvar süreçlerin başlamasında IL-6'nın da önemli rolü vardır. TNF-a ise IL-1 ve IL-6 yapımını başlatarak akut faz yanıtının giderek artmasına yol açar $(5,6)$. C-reaktif protein (CRP), eritrosit çökme hızı (EÇH), trombosit sayısı, hemoglobin düzeyi de JíA izleminde kullanılmıştır (2). Tüm bu sitokinlerin JíA'da inflamasyondaki rollerinin ortaya konulması ile birlikte hastalık aktivitesi ve sitokin düzeyleri arasındaki ilişkinin gösterilebilmesi önem kazanmıştır (1,6). Hastaların aktif dönemdeki serum sitokin seviyeleri ile hem biyolojik hem de klinik olarak hastalık aktivitesini gösteren belirteçler arasında anlamlı ilişki olduğu önceki çalışmalarda saptanmıştır. Ancak bu çalışmalarda farklı sonuçlar elde edilmiştir (7). Bugüne kadar pek çok yayında JiA hastalarında aktif dönemlere ait veriler bulunmakla birlikte hem aktif hem de inaktif dönemlerdeki sitokin düzeylerine yönelik çalışma sayısı sınırlıdır (8).
Araştırmaların bir kısmında oligoartiküler JïA alt tiplerin etyopatogenezinde farklılıklar olabileceği belirtilmiştir. Bu farklılıkları genetik altyapı ve immün sistem yanıtlarındaki değişkenlerin ortaya çıkarmış olabileceği düşünülmektedir. $(7,9)$. Bu çalışmanın amacı oligoartiküler JiA hastalarımızda aktif ve inaktif döneme ait sitokin seviyelerinin (IL-1 $\beta$, TNF-a ve IL-6) değerlendirilmesidir.

\section{GEREÇ VE YÖNTEMLER}

Bu çalışmaya, Ekim 2015-Nisan 2016 tarihleri arasında hastanemiz çocuk romatoloji kliniğine başvuran Uluslararası Romatoloji Birliği [International League of Association for Rheumatology (ILAR)]'nin JiA tanı kriterlerine (10) göre oligoartiküler JiA tanısı almış 13 yeni hasta dahil edildi. Benzer cinsiyet ve yaşta, çalışmaya alındığı dönemde herhangi bir aktif inflamasyon süreci geçirmeyen, kronik bir hastalığı ve ilaç kullanımı olmayan 8 sağlıklı çocuk kontrol grubu olarak seçildi. Çalışma hastanemiz yerel etik komitesi tarafından onaylandı (onay no=2013-070). Tüm ailelerden bilgilendirilmiş olur formu alındı. Klinik ve laboratuvar değerlendirme ilk değerlendirmeden altı ay sonra tekrarlandı. Altıncı aydaki kontrollerinde inaktif dönemde kabul edilen hastalar çalışmaya dahil edildi. Aktif eklem tutulumu, ateş yüksekliği, döküntü, serozit, splenomegali, jeneralize lenfadenopati, aktif üveit olmaması, EÇH ve CRP'nin normal olması, hekimin global değerlendirmesinde hiçbir hastalık aktivitesi göstermemesi inaktif hastalık olarak kabul edildi. IL$1 \beta$, IL-6 ve TNF-a düzeylerinin çalışılması için ilk başvurularda ve 6. aydaki kontrollerde jelli kan alma tüplerine kan örnekleri alındı. 4000 devirde 10 dakika santrifüj edildikten sonra elde edilen serum örnekleri $-80^{\circ} \mathrm{C}$ 'de muhafaza edilerek çalışma gününe kadar saklandı. Çalışmada Di̇ASource ImmunoAssays marka (Louvain-la-Neuve-Belçika) insan IL-6, IL-1 $\beta$ ve TNF-a hazır ticari ELISA (enzyme-linked immunosorbent assay) kitleri kullanıldı. Serum örnekleri kit içerisinden çıkan kullanım kılavuzuna uygun olarak çalışıldı.

Juvenil idiopatik artrit hastalık aktivite skoru 27 eklemde hesaplandı. JADAS'a (Juvenile Arthritis Disease Activity Score) göre 0-1 puan arası remisyon, 1-10 puan arası düşük aktivite düzeyi, 10-25 puan arası orta aktivite düzeyi ve 25 ve üstü puan ağır aktivite düzeyi olarak kabul edilir (11). Fonksiyonel durumun değerlendirilmesinde yaşam kalitesi ölçeklerinden faydalanıldı. Bu amaçla 'Juvenile Arthritis Quality of Life Questionnaire (JAQQ)' (Juvenil artrit yaşam kalitesi anketi) 
kullanıldı. Hesaplanan puan 1-7 arasında değişebilir ve yüksek skorlar düşük hayat kalitesini gösterir (12).

Aktif eklem, tedavi öncesi ve izlemi sırasında aynı deneyimli kişi tarafından gri-skala ultrasonografi ile değerlendirildi. Eklemde efüzyon, sinoviyal kalınlaşma ve tendinit gibi inflamasyon bulguları kaydedildi.

Altı aylık tedavi sonrasında aynı hastalardan tüm bu değerlendirmeler tekrar yapıldı, sitokin düzeyleri yeniden çalışıldı. Altı aylık süre boyunca hastaların rutin kontrolleri, tedavi değişimleri ve klinik izlemleri not edildi.

\section{İstatistiksel Analiz}

Verilerin değerlendirilmesinde Windows için SPSS (Statistical Package for Social Science) 16 kullanıldı. Tanımlayıcı istatistikler; devamlıık gösteren normal dağılımı olmayan değişkenlerde (TNF-a, İ-1 $\beta$, IL-6) ortanca, normal dağılım gösteren değişkenlerde ise ortalama \pm standart sapma (SS) olarak belirtildi. İki gruptaki değişkenlerin karşılaştııımasında; parametrik test varsayımları yerine getirilemediğinde MannWhitney $U$ testi, parametrik test varsayımları yerine getirildiğinde ise Student t testi ve ki-kare $\left(x^{2}\right)$ testi uygulandı. P değeri 0.05'in altında olan sonuçlar istatistiksel olarak anlamlı kabul edildi.

\section{BULGULAR}

Hastaların yaş ortalaması 7.36 \pm 5.2 (1.5-15.9) yıl, kontrol grubunun yaș ortalaması ise $8.25 \pm 4.94(2.5-16)(p=0.705)$ yıldı. On üç hastanın 9 (\%69.2)'u kız, 4 (\%30.8)'ü erkekti. Kontrol grubunda 6 kı (\%75) ve 2 erkek (\%25) vardı. Hastaların ilk şikâyetlerinin başlaması ile başvurularına kadar geçen süre ortalaması 8.76 aydı (2-36 ay). Bir hastada anti nükleer antikor (ANA) pozitif, bir hastada romatoid faktör (RF) pozitifti. Hiçbir hastada başvuru ve takiplerde üveit gelişmedi. Hastaların aktif dönemlerinde bakılan beyaz küre, EÇH, CRP ortalaması inaktif dönemdekiler ile karșılaștırıldığında istatistiksel olarak anlamlı fark bulunmadı (Tablo I). Aktif dönem, inaktif dönem ve kontrol gruplarının IL-6, IL-1 gruplar arasında istatistiksel olarak anlamlı fark saptanmadı (Tablo II). Hastaların ilk başvurularındaki JADAS-27 skorları ile inaktif dönemdeki JADAS-27 skorları karşılaştıııldı̆ında inaktif dönemde skorda anlamlı azalma olduğu saptandı $(p=0.02)$ (Tablo I). JADAS-27 skoru 10'un üzerinde olan hastalarla (orta ve ağır aktif) ve 10 ve altında olan (remisyon-hafif) hastaların sitokin düzeyleri karşılaştırıldığında; hastalık aktivitesi 10'un üzerinde olan hastalarda IL-1ß ortanca değerinde anlamlı yükseklik saptanırken ( $p=0.006)$, İL-6 ve TNF-a düzeylerinde fark saptanmadı (Tablo III). Hastalık aktivitesi JAQQ puanları karşılaştırıldığında ise gruplar arasında anlamlı farklılık saptanmadı (Tablo I).

Hastaların tedavilerinde 4 hastaya (\%30.8) nonsteroidal antiinflamatuvar ilaç (NSAii), 5 hastaya eklem içi steroid enjeksiyonu ve NSAil, 2 hastaya NSAil, eklem içi steroid enjeksiyonu ve metotreksat, 2 hastaya ise NSAil ve metotreksat tedavisi başlandı. Hastaların ilk başvurusunda; bir hastada hafif, 5 hastada orta düzeyde, 3 hastada ise şiddetli düzeyde sinoviyal hipertrofi vardı. Hastaların 13'ünde eklem içinde effüzyon, birinde erozyon saptandı. İnaktif dönemde bakılan eklem ultrasonografilerinde; sadece 4 hastada az miktarda sinoviyal hipertrofi saptanırken bir hastada mevcut olan erozyon devam ediyordu.

Tablo I: Aktif dönem ve inaktif dönemdeki laboratuvar parametreleri ve ölçekleme sonuçlarının karşılaştırıması.

\begin{tabular}{l|c|c|c|}
\hline & Aktif dönem & Inaktif dönem & \multicolumn{1}{c}{$\mathbf{p}$} \\
\hline EÇH (mm/saat) & $21.0 \pm 16.2(4-57)$ & $8.92 \pm 4.0(4-18)$ & 0.327 \\
\hline CRP (mg/dl) & $0.65 \pm 0.74(0.1-2.44)$ & $0.37 \pm 0.2(0.1-1)$ & 0.271 \\
\hline Hemoglobin (g/dl) & $12.44 \pm 1.22(10.6-15.3)$ & $12.43 \pm 1.41(10.6-15.8)$ & 0.721 \\
\hline Beyaz küre (/mm3) & $9761 \pm 2396(7900-15900)$ & $8730 \pm 1730(6400-12200)$ & 0.142 \\
\hline JADAS-27 (0-57) & $13.8 \pm 5.88(4-24)$ & $5.07 \pm 4.46(0-13)$ & 0.382 \\
\hline JAQQ & $2.84 \pm 1.37(0.96-6)$ & $2.48 \pm 1.46(1.08-6.59)$ & \\
\hline
\end{tabular}

EÇH: Eritrosit çökme hızı, CRP: C reaktif protein, JADAS: Juvenile Arthritis Disease Activity Score, JAQQ: Juvenile Arthritis Quality of Life Questionnaire

Tablo II: Aktif, inaktif dönem ve kontrol grubunun sitokin sonuçlarının karşılaştırılması.

\begin{tabular}{|c|c|c|c|c|c|c|}
\hline & \multirow[b]{2}{*}{ Aktif dönem } & \multirow[b]{2}{*}{ İnaktif dönem } & \multirow[b]{2}{*}{ Kontrol } & \multicolumn{3}{|c|}{$\mathbf{p}$} \\
\hline & & & & $\begin{array}{c}\text { Aktif } \\
\text { inaktif }\end{array}$ & $\begin{array}{c}\text { Aktif } \\
\text { kontrol }\end{array}$ & $\begin{array}{l}\text { Inaktif } \\
\text { kontrol }\end{array}$ \\
\hline IL-6 (pg/ml) & $210 \pm 69.89(140-340)$ & $180 \pm 162(140-700)$ & $186.2 \pm 36.6(150-250)$ & 0.929 & 0.202 & 0.799 \\
\hline IL-1及 (pg/ml) & $310 \pm 134.5(200-750)$ & $300 \pm 168.9(200-810)$ & $357 \pm 300.5(72-920)$ & 0.506 & 0.659 & 0.547 \\
\hline TNF-a (pg/ml) & $740 \pm 252.85(140-800)$ & $560 \pm 196.05(140-830)$ & $447 \pm 149(180-640)$ & 0.505 & 0.095 & 0.327 \\
\hline
\end{tabular}

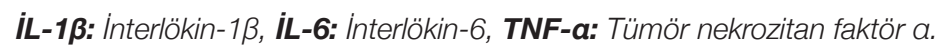


Tablo III: JADAS-27 puanı ve sitokin düzeylerinin karşılaştııılması.

\begin{tabular}{|l|c|c|c|}
\hline & JADAS-27 $>\mathbf{1 0}$ & JADAS-27 $\leq \mathbf{1 0}$ & $\mathbf{p}$ \\
\hline II-1 $\boldsymbol{\beta}$ (pg/ml) (ortanca) & 79.5 & 11.5 & 0.006 \\
\hline TNF-a (pg/ml) (ortanca) & 55 & 36 & 0.260 \\
\hline II-6 (pg/ml) (ortanca) & 62 & 29 & 0.940 \\
\hline
\end{tabular}

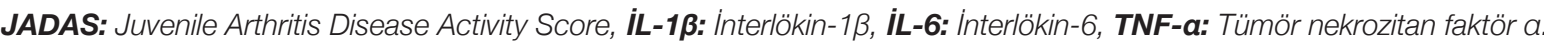

\section{TARTIŞMA}

Bu çalısma ile oligoartiküler JíA hastalarında aktif ve inaktif hastalık dönemlerindeki sitokin (IL-1 $\beta$, TNF-a ve IL-6) düzeyleri ve hastalık aktivite parametreleri değerlendirilmiştir.

Çalışmamızda hastaların hem aktif hem de inaktif dönemlerinde IL-1 $\beta$ düzeyleri çalısıldı. Aktif dönemde yüksek saptanmasına rağmen gruplar arasında istatiksiksel olarak anlamlı fark saptanmadı. Hastalık aktiviteleri orta ve ağır olan hastalarda IL$1 \beta$ değerinde anlamlı olarak yükseklik saptandı. IL-1 ve IL-1 $\beta$ aktivitesi ilk kez Prieur ve ark. tarafından çalıșılmıș ve sistemik JiA hastalarında yüksek saptanmıştır (13). Yılmaz ve ark.nın (8) çalışmasında da aktif dönemdeki sistemik ve poliartiküler JiA hastalarında IL-1 seviyelerinde sağliklı kontrol grubuna göre anlamlı yükseklik saptanmış, hastalık aktivitesi ile IL-1 $\beta$ düzeyi arasında anlamlı ilişki görülmüştür. Benzer şekilde Mangee ve ark.nın çalıșmasında da sadece sistemik JiA hastalarında yüksek seviyede IL-1ß seviyesi saptanmıştır (5). Bir başka çalışmada ise IL-1 $1 \beta$ düzeyi ile etkilenen eklem sayısı arasında özellikle poliartiküler tutulumda anlamlı ilişkili olduğu gösterilmiştir (14). Bunlardan farklı olarak bazı çalışmalarda ise JìA hastalarında kontrol grupları ile benzer seviyelerde IL-1 düzeyi saptanmıştır $(15,16)$. Yine bir başka çalışmada da tüm alt gruplarda aktif ve inaktif dönemde ölçülen IL-1 $\beta$ seviyelerinde anlamlı fark saptanmamıştır (6). Çalıșmamıza benzer şekilde Spirchez ve ark. (3) oligoartiküler JiA gruplarında kontrol grubuna benzer IL-1 seviyeleri bulmuşlardır. Tüm bu çalışmalarda ortak olarak JiA'da başta sistemik ve poliartiküler alt tiplerde olmak üzere yüksek IL-1 seviyesi saptandığı ve patogenezde bu sitokinin önemli bir rol aldığı sonucu çıkartılmıştır.

Çalışmamızda hastaların tanı anında bakılan TNF-a ve IL-6 seviyelerinde kontrol grubu ve inaktif dönem ile karşılaştırılığında istatistiksel olarak anlamlı farksaptanmamıștı. Yine hastalarımızın hastalık aktivite skorları ile bu sitokin düzeyleri arasında anlamlı bir ilișki bulunamamıştır. Yılmaz ve ark.nın (8) çalıșmasında aktif dönemlerindeki sistemik JiA ve poliartiküler JíA hastalarının IL-6 düzeyleri hem oligoartiküler hastalardan hem de kontrol grubundan anlamlı olarak yüksek saptanmış ve hastaların IL-6 seviyeleri klinik düzelme ile birlikte azalmıştır. Spirchez ve ark.nın (3) 2012 ylında yaptığı bir çalıșmada aktif hastalık dönemlerinde sistemik ve poliartiküler JiA alt tiplerinde serum IL-6 seviyelerini oligoartiküler JíA'ya göre anlamlı olarak yüksek saptamıșlardır. Madson ve ark.(17) ile De Benedetti ve ark.nın
(18) yaptığı çalışmalarda ise oligoartiküler JíA hastalarında da yüksek IL-6 seviyeleri saptanmıştır (16). Ancak JiA'da hastalık aktivitesi ve alt türü ile IL-6 düzeyi arasında anlamlı fark ve ilişki bulunmamış yayınlar da vardır $(5,19)$. Literatür bilgileri göz önüne alındığında IL-6'nın başta sistemik Ji'A olmak üzere JiA etiyopatogenezinde önemli olduğu sonucu çıkarıabilir. Spirchez ve ark. (3) hastalarından dört tanesinin sinoviyal sıvilarında da IL-6 seviyeleri çalıșmış ve hastalık alt tipinden bağımsız olarak plazma seviyelerine göre artmış İ-6 seviyesi saptamıșlardır. Yazarlar özellikle IL-6'nın diğer sitokinlerden farklı olarak inflamasyonun olduğu doku ve eklemlerden salgılanması üzerinde durmușlar ve sinoviyal SIVI IL-6 seviyelerinin hastallı aktivasyonu ve eklem harabiyetini serum seviyelerine göre daha iyi gösterebileceğini belirtmişlerdir (3).

Literatürde IL-1 ve IL-6' da olduğu gibi TNF-a düzeyleri ile ilgili olarak da farklı sonuçlar saptanmıștır. Bizim sonuçlarımıza benzer șekilde aktif dönemdeki oligoartiküler JiA hastalarında anlamlı düzeyde artmıș TNF-a düzeyi saptanmamıș ve yine hastallk aktivitesi ile arasında pozitif korelasyon bulunmamıș yayınlar vardır $(5-7,17)$. Gattorno ve ark.nın (20) yaptığı çalıșmada TNF reseptörlerinin hastalık aktivitesi ile ilișkili olduğu saptanmıș ve TNF'nin Ji'A patogenezinde etkili olduğu sonucuna varımıștır. Yine El Gazzar ve ark.nın(16) çalıșmasında hem TNF-a düzeyleri hem de TNF-a-308 A/G gen polimorfizminin JiA ve JiA aktivitesi ile ilişkili olduğu sonucuna varımış̧ı (21). Diğer bir çalıșmada 22 oligoartiküler JiA hastasının serum TNF-a seviyeleri tedavi öncesi, tedavinin 6. ayı ve 1. yllında değerlendirilmiş; tanı dönemindeki TNF-a düzeyleri ile kontrol grubu arasında anlamlı fark saptanırken, hastaların aktif ve inaktif dönemleri arasında ve inaktif dönem ile kontrol grubu arasında anlamlı fark saptanmamıștır. Yazarlar çalıșmamıza benzer șekilde TNF-a'nın oligoartiküler Ji'A hastalarında hastalık aktivitesini değerlendirmek açısından uygun bir parametre olmadığı sonucuna varmıșlardır (7).

Hastaların ilk başvurularındaki JADAS-27 skorları ile inaktif dönemdeki JADAS-27 skorları karșılaştııldığında anlamlı olarak inaktif dönemde skorda azalma olduğu saptandı. Hastalık fonksiyon değerlendirilmesinde JAQQ puanları karşılaștırılığında ise gruplar arasında anlamlı farkllık saptanmadı. Yine JADAS-27 skoruna göre orta ve ağır aktif olan hastaların IL-1ß seviyelerinde anlamlı yükseklik saptandı. Funk ve ark.nın (16) yaptı̆̆ı çalıșmada benzer şekilde tüm JiA alt gruplarında JADAS-70 skorları tedavi öncesi ve sonrası olarak karșılaștıııdığında tedavi sonrasında anlamlı düșüklük 
saptanmıştır. Ancak bu hastalarda grubumuzdan farklı olarak özellikle IL-6 seviyesi ile JADAS skoru arasında anlamlı bir ilişki bulunmuştur (16). Yine Spirchez ve ark.nın (3) yaptığı yayında tüm hasta gruplarında sitokin düzeyleri ile JADAS-27 skoru karşılaştıııımış ve çalışmamızdan farklı şekilde JADAS-27 skoru 10 ve üstü olan hastalarda sadece IL-6 seviyesi ile anlamlı bir ilişki kaydedilmiştir. Bir başka çalışmada ise sadece TNF-a düzeyleri çalışılmış ve JADAS-27 skoru ile arasında anlamlı pozitif korelasyon saptanmıştır (21). Ancak tüm bu yayınların çalışmamızdan farklı olan ortak yönü tüm JïA alt gruplarını dahil etmiş olmalarıdır. Yirmi oligoartiküler JiA hastasının değerlendirildiği bir başka yayında ise hastalık aktivite skorları ile TNF-a arasında çalışmamıza benzer şekilde herhangi bir farklılık saptanmamıştır. Bu hasta grubunda fonksiyonel değerlendirme için CHAQ (Childhood Health Assessment QuestionnaireÇocukluk Çağı Sağlık Değerlendirme Anketi) kullanılmış ve hastaların aktif ve inaktif dönemlerinde bakıldığında hasta grubumuza benzer şekilde fonksiyonel skorlamada farklllık saptanmamıştır. Yazarlar, yayınımıza benzer şekilde, hastaların oligoartiküler alt tipte olması nedeniyle anlamlı bir farklılık görülmemiş olabileceği üzerinde durmuşlardır (7). El Gazzar ve ark.nın (21) yaptığı çalışmada ise CHAQ skorları ile hastalık aktivite dönemi arasında pozitif bir ilişki bulunmuştur. Ancak bu yayında da tüm JiંA alt tipleri çalışmaya dahil edilmiştir (21).

Çalışmamızın bazı kısıtıııkları bulunmaktadır. Bunlardan birincisi ve en önemlisi hasta sayısının yetersiz olmasıdır. Aynı zamanda sadece oligoartiküler JiA hastaları alındığından diğer alt gruplar ile karşılaştırma yapılamamıştır.

Juvenil idiopatik artrit hastalarında aktif hastalık döneminde serum ve sinoviyal sıvıda sitokin düzeylerinde artış olabilir. Ancak bu hem JiA alt tiplerine hem de inflmasyonun yoğun olduğu dokuya göre farklllaşabilir. Sitokin seviyesindeki değişiklikler sadece JiA'ya özgül olmayıp farklı kronik hastalıklar ve inflamatuvar süreçlerde de yükseklik ya da farklılıklar gösterebilmektedir. Yine bazı sitokinlerin nöroendokrin sistem kontrolü altında olduğu ve diurnal ritme göre değişiklik gösterebileceği de akılda tutulmalıdır (22).

Sonuç olarak; JíA'nın doğası ve geniş bir klinik yelpazeye sahip olması nedeni ile tanı, takip ve hastalık aktivasyonlarının değerlendirilmesi aşamalarında klinisyenlerin kullanabileceği testler ve izlem belirteçleri yetersiz kalabilmektedir. Sonuçlarımız ve literatür ışığında bakıldığında; oligoartiküler JiA hastalarında sitokin düzeylerinin tanı, izlem ve hastalık aktivitesininin değerlendirilmesinde kullanılabilirliği kısıtıdır.

\section{Teşekkür}

Interlökin-1 $\beta$, IL-6 ve TNF-a düzeylerinin çalışılmasında emeği geçen kimyager Özlem İşgüzar'a ve biyolog Cihan Karadeniz'e katkılarından dolayı teşekkür ederiz.

\section{Finansal Kaynak}

Bu çalışma sırasında, yapılan araştırma konusu ile ilgili doğrudan bağlantısı bulunan herhangi bir ilaç firmasından, tıbbi alet, gereç ve malzeme sağlayan ve/veya üreten bir firma veya herhangi bir ticari firmadan, çalışmanın değerlendirme sürecinde, çalışma ile ilgili verilecek kararı olumsuz etkileyebilecek maddi ve/veya manevi herhangi bir destek alınmamıştır.

\section{Çıkar Çatışması}

Bu çalışma ile ilgili olarak yazarların ve/veya aile bireylerinin çıkar çatışması potansiyeli olabilecek bilimsel ve tıbbi komite üyeliği veya üyeleri ile ilişkisi, danışmanlık, bilirkişilik, herhangi bir firmada çalışma durumu, hissedarlık ve benzer durumları yoktur.

\section{KAYNAKLAR}

1. Petty RE, Laxer RM, Wedderburn LR (2016) Juvenile idiopathic arthritis. In: Petty RE, Laxer RM, Lindsley CB et al (eds) Textbook of pediatric rheumatology, 7th edn. Elsevier, Philadelphia, pp 188204.

2. Ravelli A, Martini A. Juvenile idiopathic arthritis. Lancet 2007;369:767-78.

3. Spîrchez M, Samaşca G, lancu M, Bolba C, Miu N. Relation of interleukin-6, TNF-alpha and interleukin-1alpha with disease activity and severity in juvenile idiopathic arthritis patients. Clin Lab 2012;58:253-60.

4. Rooney M, David J, Symons J, Di Giovine F, Varsani H, Woo P. Inflammatory cytokine responses in juvenile chronic arthritis. $\mathrm{Br} J$ Rheumatol 1995;34:454-60.

5. Mangge $H$, Kenzian $H$, Gallistl S, Neuwirth G, Liebmann P, Kaulfersch W, et al. Serum cytokines in juvenile rheumatoid arthritis. Correlation with conventional inflammation parameters and clinical subtypes. Arthritis Rheum. 1995;38:211-20.

6. Ou LS, See LC, Wu CJ, Kao CC, Lin YL, Huang JL. Association between serum inflammatory cytokines and disease activity in juvenile idiopathic arthritis. Clin Rheumatol 2002;21:52-6.

7. Kaminiarczyk-Pyzalka D, Adamczak K, Mikos H, Klimecka I, Moczko J, Niedziela M. Serum TNF-a levels and indicators of disease activity in children with oligoarticular juvenile idiopathic arthritis (OJIA) in the first year of the disease. Clin Lab 2014;60:799807.

8. Yilmaz M, Kendirli SG, Altintas D, Bingöl G, Antmen B. Cytokine levels in serum of patients with juvenile rheumatoid arthritis. Clin Rheumatol 2001;20:30-5.

9. Macaubas C, Nguyen K, Milojevic D, Park JL, Mellins ED. Oligoarticular and polyarticular JIA: epidemiology and pathogenesis. Nat Rev Rheumatol 2009;5:616-26.

10. Petty RE, Southwood TR, Manners P, Baum J, Glass DN, Goldenberg J, et al. International League of Associations for Rheumatology classification of juvenile idiopathic arthritis: second revision, Edmonton, 2001. J Rheumatol 2004;31:390-2.

11. Consolaro A, Giancane G, Schiappapietra B, Davì S, Calandra S, Lanni S, et al. Clinical outcome measures in juvenile idiopathic arthritis. Pediatr Rheumatol Online J 2016;14:23.

12. Amine B, Rostom S, Benbouazza K, Abouqal R, Hajjaj-Hassouni N. Health Related quality of life survey about children and adolescents with juvenile idiopathic arthritis. Rheumatol Int 2009;29:275-9.

13. Prieur AM, Kaufmann MT, Griscelli C, Dayer JM. Specific interleukin-1 inhibitor in serum and urine of children with systemic juvenile chronic arthritis. Lancet 1987;2:1240-2. 
14. Alarcon-Riquelme ME, Vazquez-Mellado J, Gomez-Cordillo M, Alcocer-Varela J, Burgos-Vargas R, Alarco 'n-Segovia D. Immuoregulatory defects in juvenile rheumatoid arthritis: Comparison between patients with systemic or polyarticular forms. J Rheumatol 1988;15:1547-50.

15. Sandborg Cl, Berman MA, Andrews BS, Mirick GR, Friou GJ. Increased production of an interleukin-1 inhibitor with fibroblast stimulation activity by mononuclear cells from patients with scleroderma. Clin Exp Immunol 1986;66:321-9.

16. Funk RS, Chan MA, Becker ML. Cytokine Biomarkers of Disease Activity and Therapeutic Response after Initiating Methotrexate Therapy in Patients withJuvenile Idiopathic Arthritis. Pharmacotherapy 2017;37:700-711.

17. Madson KL, Moore TL, Lawrence JM, 3rd, Osborn TG. Cytokine levels in serum and synovial fluid of patients with juvenile rheumatoid arthritis. The Journal of rheumatology 1994;12:2359-63.

18. De Benedetti F, Robbioni P, Massa M, Viola S, Albani S, Martini A. Serum interleukin-6 levels and joint involvement in polyarticular and pauciarticular juvenile chronic arthritis. Clin Exp Rheumatol 1992;5:493-8.
19. Lepore L, Pennesi M, Saletta S, Perticarari S, Presani G, Prodan M. Study of IL-2, IL-6, TNF alpha, IFN gamma and beta in the serum and synovial fluid of patients with juvenile chronic arthritis. Clin Exp Rheumatol 1994;5:561-5.

20. Gattorno M, Picco P, Buoncompagni A, Stalla F, Facchetti P, Sormani MP, et al. Serum p55 and p75 tumor necrosis factor receptors as markers of disease activity in juvenile chronic arthritis. Ann Rheum Dis 1996;55:243-7.

21. El Gazzar II, Fathy HM, Gheita TA, Nour El-Din AM, Rasheed EA, Bassyouni $\mathrm{RH}$, et al. Tumor necrosis factor-a $-308 \mathrm{~A} / \mathrm{G}$ gene polymorphism in children with juvenile idiopathic arthritis: relation to disease activity, damage, and functional status. Clin Rheumatol 2017;36:1757-63.

22. Woo P. Cytokines and juvenile idiopathic arthritis. Curr Rheumatol Rep 2002;4:452-7. 